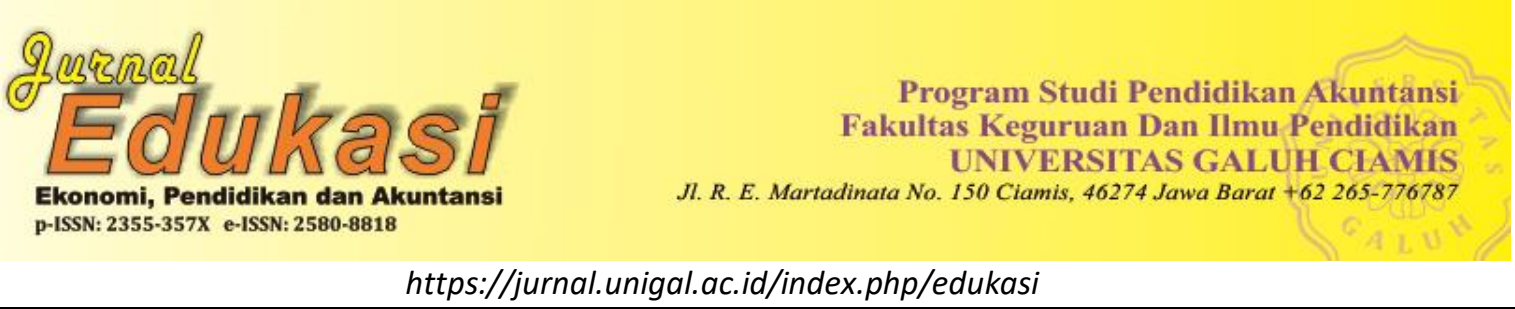

\title{
IMPLEMENTASI MEDIA PEMBELAJARAN AUDITIF TERHADAP HASIL BELAJAR PESERTA DIDIK
}

\author{
Oleh: \\ Rini Agustin Eka Yanti', Noviyanti Adhawiyah ${ }^{2}$ \\ Program Studi Pendidikan Akuntansi Universitas Galuh, Indonesia \\ Email: riniagustin.eka@gmail.com \\ Sejarah Artikel: Diterima September 2019, Disetujui Oktober 2019, Dipublikasikan November 2019
}

\begin{abstract}
ABSTRAK
Latar belakang penelitian ini adalah pencapaian kegiatan belajar mengajar terjadi apabila siswa mampu mengikuti proses pembelajaran yang diberikan oleh guru di dalam kelas. Media pembelajaran memiliki peran untuk membantu meningkatkan hasil belajar siswa. Tujuan penelitian ini adalah 1) untuk mengetahui hasil belajar siswa di kelas eksperiman pada pengukuran awal dan pengukuran akhir. 2) untuk mengetahui peningkatan hasil belajar siswa di kelas eksperimen. 3) untuk mengetahui apakah terdapat pengaruh penerapan media pembelajaran auditif terhadap hasil belajar siswa. Penelitian menggunakan metode eksperimen, Teknik analisis data menggunakan uji N-Gain dan uji Hipotesis menggunakan Uji t-test. Hasil penelitian menunjukan 1) terdapat perbedaan hasil belajar siswa pada pengukuran awal dan pengukuran akhir. 2) terdapat peningkatan hasil belajar siswa pada kategori tinggi di kelas eksperimen. 3) terdapat pengaruh penerapan media pembelajaran auditif terhadap hasil belajar siswa.
\end{abstract}

Kata Kunci: Media pembelajaran Auditif, Hasil Belajar

\section{ABSTRACT}

The background of study of this research is the achievement of teaching and learning activities occur when students are able to follow the learning process provided by the teacher in the classroom. Learning media has a role to improve student learning outcomes. The purpose of this study is 1) to determine student learning outcomes in experimental classes on pretest and posttest. 2) to find out the improvement of student learning outcomes in the experimental class. 3) to find out whether there is an influence of the application of auditive learning media on student learning outcomes. The study used an experimental method, the technique of data analysis used the N-Gain test and the Hypothesis test used the t-test. The results showed 1) there are differences in student learning outcomes in the pretest and final measurement. 2) there is an increase in student learning outcomes in the high category in the experimental class. 3) there is an effect of the application of auditive learning media on student learning outcomes

Keywords: auditive learning media, learning outcomes

\section{PENDAHULUAN}

Kegiatan utama dalam proses pendidikan di sekolah adalah pembelajaran. Pembelajaran atau belajar mengajar mengacu pada pengertian sebagai seperangkat komponen yang saling bergantung satu sama lain. Adapun arti belajar itu sendiri adalah proses perubahan berkat pengalaman dan pelatihan (Syaful dan Aswan, 2010:10). Belajar mengajar adalah suatu kegiatan yang bernilai edukatif mewarnai interaksi yang terjadi antara guru dengan peserta didik. Interaksi yang bernilai edukatif dikarenakan kegiatan belajar mengajar yang dilakukan, diarahkan untuk mencapai tujuan 
tertentu yang telah dirumuskan sebelum pengajarannya secara sistematis dengan memanfaatkan segala sesuatunya guna kepentingan pengajaran.

Setiap pendidik mengharapkan bagaimana bahan pelajaran yang disampaikan dapat dikuasai peserta didik secara tuntas. Ini merupakan masalah yang cukup sulit yang dirasakan oleh guru. Kesulitan ini dikarenakan peserta didik bukan hanya sebagai individu dengan banyak keunikan, tetapi mereka juga sebagai makhluk sosial dengan latar belakang berbeda-beda, paling sedikit ada tiga aspek yang membedakan peserta didik yang satu dengan yang lainnya, yaitu aspek intelektual, psikologis, dan biologis. Ketiga aspek tersebut diakui sebagai akar permasalaahan yang melahirkan bervariasinyan sikap dan tingkah laku peserta didik di sekolah. Hal itu pula menjadi tugas cukup berat bagi guru dalam mengelola kelas dengan baik. Keluhaan-keluhan guru sering

terlontar hanya karena masalah sukarnya mengelola kelas yang kadang kurang didukungnya penggunaan media dan sumber belajar, dan penggunaan metode dan strategi pembelajaran yang kurang tepat.

Kesulitan itu ternyata dirasakan juga oleh pendidik di SMK HEPWETI Ciamis, dimana hasil belajar yang didapat peserta didik kurang memuaskan khususnya dalam mata pelajaran ekonomi bisnis. Observasi awal yang dilakukan penulis di SMK HEPWETI Ciamis Tahun Ajaran 2018/2019 yaitu pada kelas X AK 1 dan $\mathrm{X}$ AK 2 diperoleh data yang menunjukan masih banyak nilai ekonomi yang kurang dari tuntas. Hal ini dibuktikan dengan nilai mata pelajaran ekonomi bisnis di ujian akhir semester ganjil siswa kelas $\mathrm{X}$ banyak di bawah standar ketuntasan yang telah ditetapkan oleh sekolah yaitu 78. Untuk lebih jelasnya dilampirkan tabel ketuntasan belajar peserta didik dalam bentuk nilai ujian akhir semester (UAS):

Tabel 1:

Nilai Ujian Akhir Semester Siswa Kelas X SMK HEPWETI Ciamis Semester Ganjil Tahun Ajaran 2017/2018 Mata Pelajaran Ekonomi Bisnis

\begin{tabular}{|c|c|c|c|c|c|c|c|c|c|}
\hline \multirow[b]{2}{*}{ No } & \multirow[b]{2}{*}{ Kelas } & \multirow[b]{2}{*}{ Kkm } & \multirow{2}{*}{$\begin{array}{c}\text { Jumlah } \\
\text { siswa }\end{array}$} & \multicolumn{3}{|c|}{ Nilai } & \multicolumn{2}{|c|}{ Jumlah Siswa } & \multirow{2}{*}{$\begin{array}{c}\text { Tidak } \\
\text { Tuntas } \\
\%\end{array}$} \\
\hline & & & & Terendah & Tertinggi & $\begin{array}{c}\text { Rata- } \\
\text { rata }\end{array}$ & Tuntas & $\begin{array}{c}\text { Tidak } \\
\text { Tuntas }\end{array}$ & \\
\hline 1 & X AK1 & 78 & 21 & 69 & 80 & 72,8 & 8 & 13 & $62 \%$ \\
\hline 2 & $\mathrm{X}$ AK2 & 78 & 20 & 69 & 80 & 73,1 & 9 & 11 & $55 \%$ \\
\hline & JUMLA & & 41 & & & & 17 & 23 & $56 \%$ \\
\hline
\end{tabular}

Sumber: Guru ekonomi kelas X SMK HEPWETI Ciamis Tahun Ajaran 2017/2018.

Berdasarkan tabel 1 diatas nilai prosentase belum mencapai kriteria ketuntasan minimal (KKM) yang ditargetkan minimal $90 \%$ dari peserta didik per kelasnya. Sedangkan kenyataannya peserta didik yang tidak tuntas untuk mata pelajaran ekonomi bisnis sebanyak 13 orang di kelas $X$ akutansi 1 dan 11 orang dari kelas $\mathrm{X}$ akutansi 2. Hal ini menunjukan bahwa masih banyak siswa yang belum tuntas untuk mata pelajaran ekonomi bisnis.

Pembelajaran ekonomi bisnis yang diperlukan saat ini adalah pembelajaran yang dapat meningkatkan penguasaan konsep materi dan hasil belajar peserta didik sehingga semakin baik. Pendidik bisa memanfaatkan penggunaan media pembelajaran sebagai alat bantu. Azhar Arsyad (2017:29) mengemukakan bahwa "media pembelajaran dapat mempemperjelas penyajian pesan dan informasi sehingga dapat memperlancar dan meningkatkan proses dan hasil belajar". Adapun manfaat media pembelajaran menurut Aqib (2013) yaitu: “(1) menyeragamkan penyampaian materi, (2) pembelajaran lebih jelas dan menarik, (3) proses pembelajaran lebih interaksi, (4) efisiensi waktu dan tenaga, (5) meningkatkan kualitas hasil belajar, (6) belajar dapat dilakukan kapan saja, (7) menumbuhkan sikap posistif belajar terhadap proses dan materi belajar, (8) meningkatkan peran guru ke arah yang lebih posistif dan produktif".

Salah satu media pembelajaran yang dapat digunakan oleh guru sebagai alat bantu kegiatan pembelajaran yaitu media Auditif atau Audio. Auditif atau Audio merupakan media pembelajaran inovasi yang sesuai untuk meningkatkan hasil belajar peserta didik dalam pembelajaran ekonomi bisnis yang akan menggabungkan antara kemampuan mendengar siswa dengan pemusatan perhatian, hingga peserta didik dapat mengulang kembali informasi atau materi dalam bentuk tulisan 
maupun pemaparan untuk mengetahui sejauh mana siswa memahami materi yang disampaikan. Hal itu di sebutkan dalam beberapa keterampilan yang didapatkan melalui penggunaan media Auditif atau Audio menurut Kustandi dan Sutjipto (2013:58) yaitu :

1) Pemusatan perhatian.

2) Mengikuti arahan.

3) Melatih daya analisis.

4) Menentukan arti dan konteks.

5) Memilih-milih informasi atau gagasan yang relevan dan informasi yang tidak relevan.

6) Merangkum, mengemukakan kembali, atau mengingat kembali informasi.

Penggunaan alat bantu atau media pembelajaran merupakan bagian yang tidak bisa dipisahkan dan sudah merupakan suatu integrasi terhadap metode belajar yang dipakai. Alat bantu belajar termasuk salah satu unsur dinamis dalam belajar karena pada hakikatnya Kegiatan belajar ditandai oleh adanya kegiatan pengelolaan kelas, penggunaan media pembelajaran dan Sumber belajar, dan penggunaan metode dan strategi pembelajaran (Rusman, 2012:76).

Media pembelajaran memiliki peranan yang penting untuk membantu proses pembelajaran lebih efektif dan dapat menarik perhatian peserta didik, juga dapat mencaritahu seberapa besar pemahaman peserta didik dalam bentuk hasil belajar peserta didik dengan menggunakan media pembelajaran Auditif.

Hasil belajar peserta didik merupakan output dari proses belajar mengajar. Perolehan hasil belajar ini berdasarkan pada proses pembelajaran yang dipengaruhi oleh penggunaan media pembelajaran auditif atau audio.
Berdasarkan hal tersebut maka kajian ini dianggap penting untuk diteliti yang akan penulis kaji dalam sebuah penelitian dengan judul "Pengaruh Penggunaan Media Pembelajaran Auditif Terhadap Hasil Belajar Peserta Didik".

\section{METODE PENELITIAN}

Metode penelitian diartikan sebagai cara ilmiah untuk mendapatkan data dengan tujuan dan kegunaan tertentu (Sugiyono, 2017:3). Metode penelitian yang digunakan meneliti masalah yang telah dikemukakan diatas yaitu menggunakan metode penelitian eksperimen. Menurut Sugiyono (2017:11) bahwa "penelitian eksperimen merupakan metode penelitian yang digunakan untuk mencari pengaruh treatment (perlakuan) tertentu".

\section{Tabel 1}

\section{Desain penelitian}

Menurut (Sugiyono 2017:79). Desain penelitian yang digunakan adalah Nonequivelent Control Group Design(pre test-post test) Control Group Design

$$
\frac{o_{1} \times O_{2}}{o_{3} o_{4}}
$$

Keterangan

$\mathrm{X}$ : perlakuan (treament)dengan menggunakan model pembelajaran treffinger

$O_{1} \quad$ : pre tes kelompok eksperimen

$\mathrm{O}_{2}$ : post tes kelompok eksperimen

$\mathrm{O}_{3}$ : pre tes kelompok kontrol

$\mathrm{O}_{4} \quad$ : post tes kelompok kontrol 


\section{HASIL PENELITIAN DAN PEMBAHASAN}

Untuk mengetahui hasil belajar peserta didik yang menggunakan media auditif atau audio bisa dilihat dalam tabel berikut:

Tabel 2:

Hasil Pretest Dan Posttest Kelas Eksperimen

\begin{tabular}{lrrlrr}
\hline Kode Responden & Pretets & Posttets & Kode Responden & Pretets & Posttets \\
\hline Eksp 1 & 46,9 & 93,4 & Eksp 11 & 33,5 & 100 \\
Eksp 2 & 53,6 & 93,4 & Eksp 12 & 26,8 & 86,7 \\
Eksp 3 & 46,9 & 80 & Eksp 13 & 26,8 & 86,7 \\
Eksp 4 & 53,6 & 86,7 & Eksp 14 & 20,1 & 86,7 \\
Eksp 5 & 40,2 & 93,4 & Eksp 15 & 46,9 & 100 \\
Eksp 6 & 40,2 & 93,4 & Eksp 16 & 20,1 & 93,4 \\
Eksp 7 & 46,9 & 93,4 & Eksp 17 & 80,4 & 80 \\
Eksp 8 & 26,8 & 93,4 & Eksp 18 & 33,5 & 86,7 \\
Eksp 9 & 40,2 & 80 & Eksp 19 & 26,8 & 93,4 \\
Eksp 10 & 26,8 & 93,4 & Eksp 20 & 33,5 & 86,7 \\
& & & Eksp 21 & 40,2 & 93,4 \\
\hline Jumlah & & & & 810,7 & 1894,2 \\
\hline Rata-Rata & & & & 38,6 & 90,2 \\
\hline
\end{tabular}

Hasil Penelitian Tentang Peningkatan hasil belajar peserta didik yang menggunakan media pembelajaran auditif pada pengukuran awal (pretest) dan pengukuran akhir (posttest) pada kelas Eksperimen

Berikut langkah-langkah yang digunakan untuk mengukur perbedaan hasil belajar peserta didik yang tidak menggunakan media pembelajaran auditif pada pengukuran awal pretets dan pengikuran akhir posttest sebagai berikut:

1. Mengumpulkan data hasil pretest dan posttest.

Data hasil belajar peserta didik pada pengukuran awal (pretets) dan pengukuran akhir (posttest) pada kelas kontrol adalah sebagai berikut:

Tabel 3:

Hasil Pretest Dan Posttest Kelas Eksperimen

\begin{tabular}{lrrlrr}
\hline Kode Responden & Pretets & Posttets & Kode Responden & Pretets & Posttets \\
\hline Eksp 1 & 46,9 & 93,4 & Eksp 12 & 26,8 & 86,7 \\
Eksp 2 & 53,6 & 93,4 & Eksp 13 & 26,8 & 86,7 \\
Eksp 3 & 46,9 & 80 & Eksp 14 & 20,1 & 86,7 \\
Eksp 4 & 53,6 & 86,7 & Eksp 15 & 46,9 & 100 \\
Eksp 5 & 40,2 & 93,4 & Eksp 16 & 20,1 & 93,4 \\
Eksp 6 & 40,2 & 93,4 & Eksp 17 & 80,4 & 80 \\
Eksp 7 & 46,9 & 93,4 & Eksp 18 & 33,5 & 86,7 \\
Eksp 8 & 26,8 & 93,4 & Eksp 19 & 26,8 & 93,4 \\
Eksp 9 & 40,2 & 80 & Eksp 20 & 33,5 & 86,7 \\
Eksp 10 & 26,8 & 93,4 & Eksp 21 & 40,2 & 93,4 \\
Eksp 11 & 33,5 & 100 & & & \\
\hline Jumlah & \multicolumn{7}{c}{} & & & \\
\hline Rata-Rata & \multicolumn{7}{c}{38,7} & 1894,2 \\
\hline
\end{tabular}


2. Menghitung $\mathrm{N}-$ Gain Dari data diatas, dengan rumus seperti berikut:

$$
N-\text { Gain }=\frac{\text { SKOR POSTEST }- \text { SKOR PRETSET }}{\text { SMI-SKOR PRETEST }}
$$

(Meltzer, dalam Elida: 2012)

Keterangan :

Tinggi atau rendahnya nilai N-Gain

SMI = Skor Maksimal Ideal

Berikut hasil dari perhitungan N-Gain yang di sajikan dalam tabel

Tabel 4:

Hasil Perhitungan N-Gain Kelas Eksperimen

\begin{tabular}{lrc}
\hline Kode Responden & N-Gain & Keterangan \\
\hline Eksp 1 & 0,88 & Tinggi \\
Eksp 2 & 0,86 & Tinggi \\
Eksp 3 & 0,62 & sedang \\
Eksp 4 & 0,71 & Tinggi \\
Eksp 5 & 0,89 & Tinggi \\
Eksp 6 & 0,89 & Tinggi \\
Eksp 7 & 0,88 & Tinggi \\
Eksp 8 & 0,91 & Tinggi \\
Eksp 9 & 0,67 & Sedang \\
Eksp 10 & 0,91 & Tinggi \\
Eksp 11 & 1 & Tinggi \\
Eksp 12 & 0,82 & Tinggi \\
Eksp 13 & 0,82 & Tinggi \\
Eksp 14 & 0,83 & Tinggi \\
Eksp 15 & 1 & Tinggi \\
Eksp 16 & 0,92 & Tinggi \\
Eksp 17 & 0 & Rendah \\
Eksp 18 & 0,8 & Tinggi \\
Eksp 19 & 0,91 & Tinggi \\
Eksp 20 & 0,8 & Tinggi \\
Eksp 21 & 0,89 & Tinggi \\
\hline Jumlah & 170 & \\
\hline Rata-rata & 0,81 & \\
\hline
\end{tabular}

Menurut Hernani \& Aisyah (dalam Putra, Irwan \& Vionanda, 2012) tinggi atau rendahnya nilai $\mathrm{N}-$ Gain ditentukan berdasarkan kriteria berikut:

Tabel 5

Interpretasi N-Gain

\begin{tabular}{cc} 
N-Gain & Kriteria \\
\hline $\mathrm{g}>0,70$ & Tinggi \\
$0,30<\mathrm{g} \leq 0,70$ & Sedang \\
$\mathrm{g} \leq 0,30$ & Rendah
\end{tabular}

(Sundayana, 2016, P.151) 
Dari data diatas dapat dilihat dari rata rata nilai $\mathrm{N}$-gain kelas eksperimen adalah 0,81 dan dilihat dari tabel 4.3 yaitu interprestasi $\mathrm{N}$-gain berarti kelas eksperimen memiliki interprestasi $\mathrm{N}$-gain yang tinggi artinya kelas eksperimen mengalami peningkatan dari nilai pretets ke nilai post tets dengan peningkatannya yang tinggi. Bila nilai tersebut dituangkan dalam bentuk grafik maka terlihat sebagai berikut:

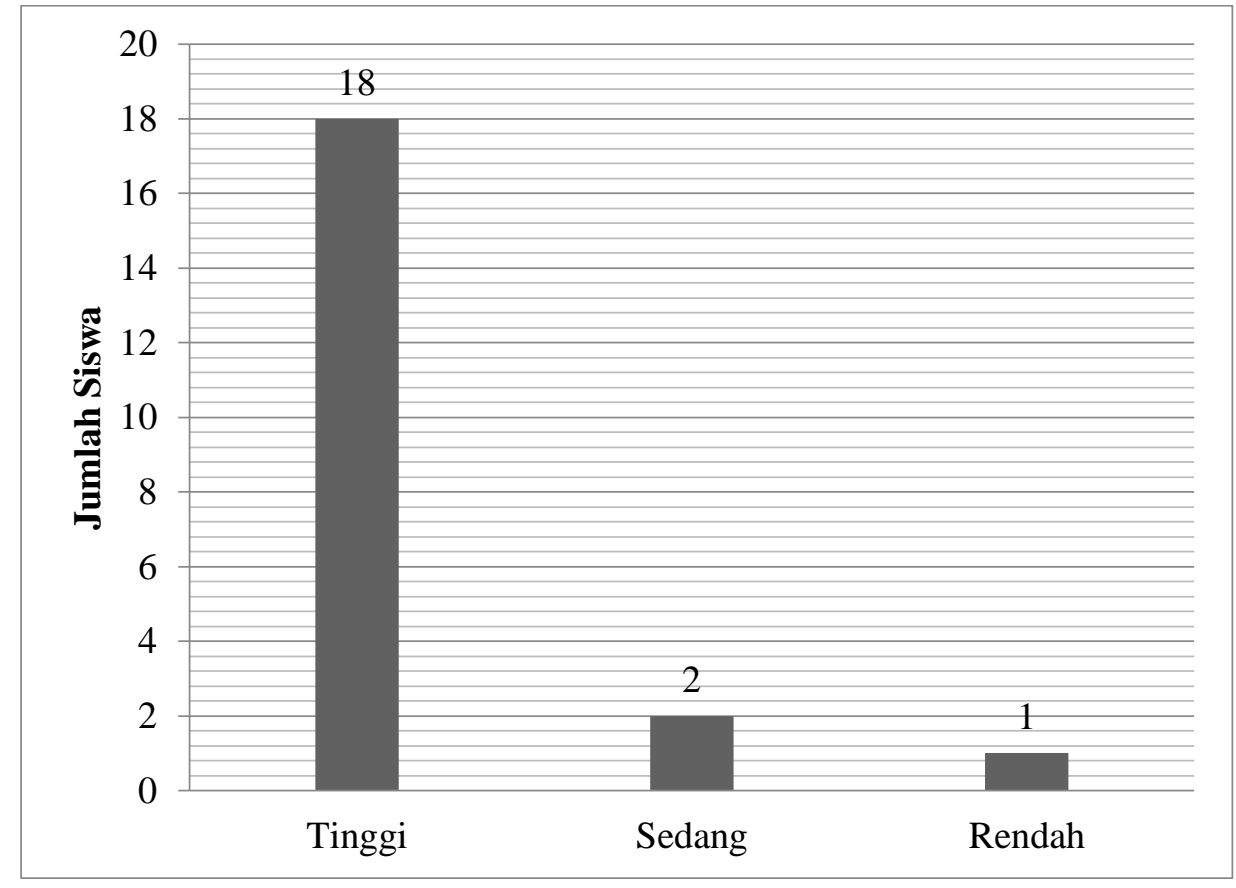

Gambar 1:

Kategori N-Gain kelas eksperimen

Dari gambar grafik diatas dapat disimpulkan bahwa terdapat peningkatan hasil belajar, dilihat dari jumlah peseta didik dengan kategori interpretasi N-Gain yang tinggi sebanyak 18 orang.

Hasil Penelitian Tentang Pengaruh Penggunaan Media Pembelajaran Auditif Terhadap Hasil Belajar Peserta Didik Di Kelas Eksperimen Dalam Mata Pelajaran Ekonomi Bisnis.

Untuk mengetahui pengaruh penggunaan media pembelajaran auditif terhadap hasil belajar peserta didik yang menggunakan media pembelajaran auditif yang dilakukan dikelas eksperimen bisa dengan membandingkan dan melihat selisih nilai pretest (pengukuran awal), posttest (pengukuran akhir) dan N-Gain pada kelas eksperimen dan kontrol pada tabel berikut:

Tabel 6:

Selisih pretets dan posttest

\begin{tabular}{|c|c|c|c|c|c|c|c|c|}
\hline \multirow[t]{2}{*}{ No } & \multirow[t]{2}{*}{ Nilai kelas } & \multicolumn{3}{|c|}{ Nilai rata-rata } & \multicolumn{3}{|c|}{$\begin{array}{l}\text { Selisih nilai rata-rata kelas } \\
\text { eksperimen dan kontrol }\end{array}$} & \multirow{2}{*}{$\begin{array}{l}\text { Selisih nilai } \\
\text { rata-rata } \\
\text { pretetst dan } \\
\text { protets }\end{array}$} \\
\hline & & Pretetst & Posttets & $\begin{array}{l}\mathrm{N}- \\
\text { Gain }\end{array}$ & Pretetst & Posttets & $\mathrm{N}$-gain & \\
\hline 1 & Eksperimen & 38,6 & 90,2 & 0,81 & \multirow[t]{3}{*}{6,29} & \multirow[t]{3}{*}{15,8} & \multirow[t]{3}{*}{28,09} & 51,6 \\
\hline 2 & Kontrol & 44,89 & 74,4 & 28,9 & & & & 29,5 \\
\hline$\sum$ & & 83,49 & 164,6 & 29,71 & & & & 81,1 \\
\hline
\end{tabular}

Dari data diatas diperoleh gambaran perbedaan nilai antara kelas kontrol dan kelas eksperimen pretets 38,6 , posttest 90,2, dan N-Gain 0,81 sedangkan selisish nilai antara postest dan pretest pada kelas kontrol adalah 29,5, sedangkan pada kelas eksperimen 51,6. Hal ini menunjukan adanya pengaruh dari 
penggunaan media pembelajaran auditif pada kelas eksperimen dalam mata pelajaran ekonomi bisnis dengan kompetensi dasar hukum permintaan dan penawaran.

Sementara itu peserta didik dalam proses pembelajaran kelas eksperimen mengalami peningkatan terbukti dari hasil pretets menunjukan 38,60\% dan mengalami peningkatan di lihat dari nilai post test sebesar 90,2\%, sedangkan di kelas kontrol pretest 44,89\% dan mengalami peningkatan yang tidak terlalu signifikan dilihat dari nilai post tets sebesar 74,4 \%. Pada kenyataannya dikelas kontrol masih banyak peserta didik yang belum memenuhi Kriteria Ketuntasan Minimum (KKM) dengan nila 78. Bila nilai tersebut dituangkan dalam bentuk grafik maka terlihat sebagai berikut:

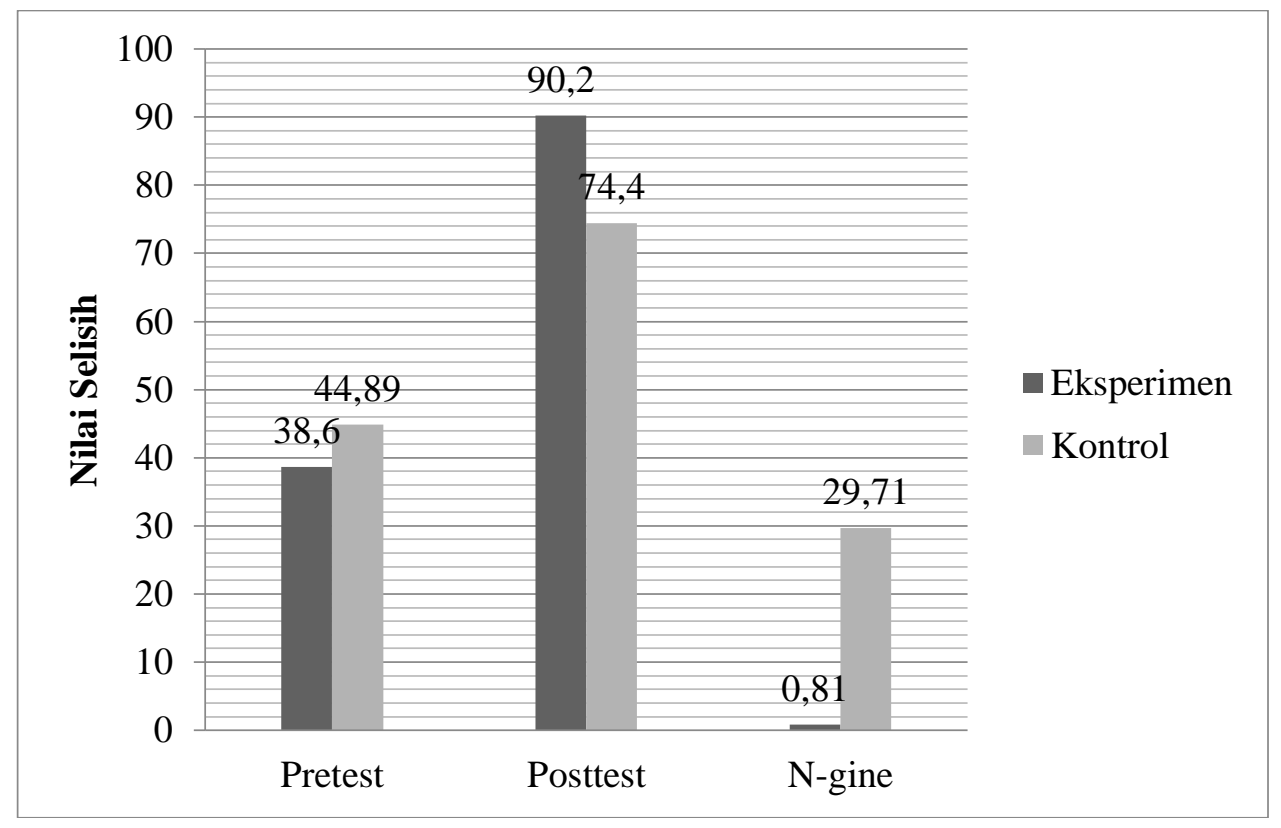

Gambar 2:

Selisih Rata-Rata Nilai Kelas Eksperimen Dan Kontrol

\section{Pengujian Hipotesis}

Berdasarkan kerangka pemikiran, hipotesis yang diajukan dalam penelitian ini adalah "Pengguunaan Media Auditif Berpengaruh Terhadap Hasil Belajar peserta didik di kelas X akutansi SMK HEPWETI Ciamis". Alat uji yang digunakan untuk membuktikan hipotesis menggunakan uji t atau uji t test menurut Sugiyono (2013:197), rumus uji t sebagai berikut:

$$
t=\frac{X_{1}+X_{2}}{\sqrt{\frac{\left(S_{1}\right)^{2}}{\left(n_{1}\right)^{2}}+\frac{\left(S_{2}\right)^{2}}{\left(n_{2}\right)}}}
$$

Keterangan:

$\bar{X} \quad=$ Nilai rata-rata posttets kelas eksperimen

$\bar{X} \quad=$ Nilai rata-rata posttets kelas kontrol

$S_{1} \quad=$ Standar deviasi kelas eksperimen

$S_{1} \quad=$ Standar deviasi kelas kontrol

Berikut langah-langkah yang digunakan untuk pengujian hipotesis dengan mengukur peningkatan peningkatan hasil belajar peserta didik menggunakan media auditif untuk melihat apakah penggunaan media pembelajaran auditif berpengaruh terhadap hasil belajar atau tidak. Pada pengukuran akhir 
(posttest) kelas eksperimen dan pengukuran akhir (posttest) kelas kontrol dengan menggunakan uji ttest sebagai berikut:

1. Membuat tabel persiapan perbedaan antara test akhir kelas eksperimen dengan test akhir kelas kontrol.

Tabel 7

Perhitungan Uji t-test hasil belajar peserta didik kelas eksperimen dan control

\begin{tabular}{lrrrrrr}
\hline \multicolumn{1}{c}{ NO } & \multicolumn{1}{c}{ X1 } & $\mathbf{X 2}$ & \multicolumn{1}{c}{ X1' } & \multicolumn{1}{c}{ X2' } & X1'2 & \multicolumn{1}{c}{ X2'2 } \\
\hline 1 & 93,4 & 70 & 3,2 & $-4,4$ & 10,2 & 19,36 \\
2 & 93,4 & 70 & 3,2 & $-4,4$ & 10,2 & 19,36 \\
3 & 80 & 78 & $-10,2$ & 3,6 & 104 & 12,96 \\
4 & 86,7 & 78 & $-3,5$ & 3,6 & 12,3 & 12,96 \\
5 & 93,4 & 78 & 3,2 & 3,6 & 10,2 & 12,96 \\
6 & 93,4 & 70 & 3,2 & $-4,4$ & 10,2 & 19,36 \\
7 & 93,4 & 78 & 3,2 & 3,6 & 10,2 & 12,96 \\
8 & 93,4 & 70 & 3,2 & $-4,4$ & 10,2 & 19,36 \\
9 & 80 & 60 & $-10,2$ & $-14,4$ & 104 & 207,36 \\
10 & 93,4 & 80 & 3,2 & 5,6 & 10,2 & 31,36 \\
11 & 100 & 75 & 9,8 & 0,6 & 96 & 0,36 \\
12 & 86,7 & 75 & $-3,5$ & 0,6 & 12,3 & 0,36 \\
13 & 86,7 & 70 & $-3,5$ & $-4,4$ & 12,3 & 19,36 \\
14 & 86,7 & 75 & $-3,5$ & 0,6 & 12,3 & 19,36 \\
15 & 100 & 70 & 9,8 & $-4,4$ & 96 & 19,36 \\
16 & 93,4 & 75 & 3,2 & 0,6 & 10,2 & 0,36 \\
17 & 80 & 78 & $-10,2$ & 3,6 & 104 & 12,96 \\
18 & 86,7 & 78 & $-3,5$ & 3,6 & 12,3 & 12,96 \\
19 & 93,4 & 80 & 3,2 & 5,6 & 10,2 & 31,36 \\
20 & 86,7 & 80 & $-3,5$ & 5,6 & 12,3 & 31,36 \\
21 & 93,4 & & 3,2 & - & 10,2 & - \\
$\sum$ & 1894,2 & 1488 & 0,0 & 0,0 & 680 & 496,8 \\
\hline Rata-rata & 90,2 & 74,4 & 0,0 & 0,0 & 32,38 & 24,84 \\
\hline
\end{tabular}

Keterangan:

$\mathrm{X} 1=$ Nilai posttest kelas eksperimen

$\mathrm{X} 2=$ Nilai posttest kelas kontrol

$\mathrm{X} 1{ }^{\prime}=\mathrm{X} 1-\bar{X} 1$

$\mathrm{X} 2{ }^{\prime}=\mathrm{X} 2-\bar{X} 2$

Sebelum menghitung $\mathrm{t}_{\text {hitung }}$ terlebih dahulu harus mencari nilai standar deviasi kedua varian dan rata-rata varian, Dengan langkah sebagai berikut:

1. Menentukan mean atau rata-rata

$$
\bar{X} 1=\frac{\sum X_{1}}{n_{1}}
$$

$$
\bar{X} 2=\frac{\sum X_{2}}{n_{2}}
$$

Sugiyono (2015:49)

$$
\bar{X} 1=\frac{1894,2}{21}=90,2 \quad \bar{X} 2 \frac{1488}{20}=74,4
$$


2. Menentukan simpangan baku atau standar deviasi

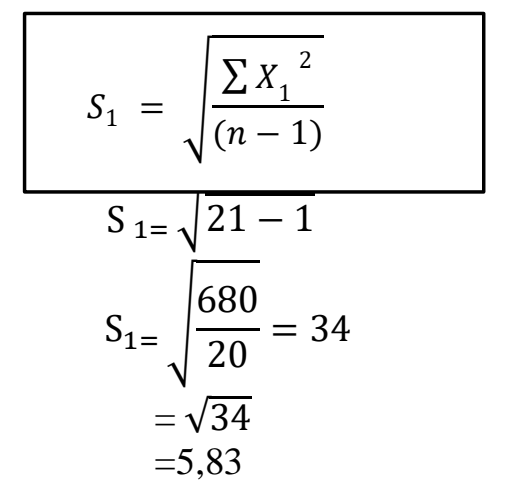

$$
\begin{gathered}
S_{2}=\sqrt{\frac{\sum\left(X_{2}^{2}\right.}{(n-1)}} \\
S_{1=\sqrt{20-1}} \\
S_{1}=\sqrt{\frac{496,8}{19}}=26 \\
S_{1=} \sqrt{26} \\
=5
\end{gathered}
$$

Berdasarkan perhitungan diatas, diperoleh standar deviasi kelas eksperimen sebesar 5,83 dan kontrol sebesar 5.

Menentukan derajat kebebasan (dk)

$\mathrm{dk}=n_{1}+n_{2}-2$

$\mathrm{dk}=21+20-2=39$

dengan taraf kepercayaan 95\% (taraf nyata $a=0,05$

Menentukan $t_{\text {hitung }}$ dengan rumus t-test, rumus t-test yang digunakan untuk pengujian hipotesis adalah rumus polled varians dengan sebagai berikut :

$$
\begin{aligned}
& t=\frac{\bar{X}_{1}-\bar{X}_{2}}{\sqrt{\frac{\left(n_{1}-1\right) \mathrm{S}_{1}^{2+}\left(\mathrm{n}_{2}-1\right) \mathrm{S}_{2}^{2}}{\mathrm{n}_{1}+\mathrm{n}_{2}-2}\left[\frac{1}{\mathrm{n}_{1}}+\frac{1}{\mathrm{n}_{2}}\right]}} \\
& t=\frac{90,2-74,4}{\sqrt{\frac{(21-1) 5,83^{2}+(20-1) 5^{2}}{21+20-2}\left[\frac{1}{21}+\frac{1}{20}\right]}} \\
& t=\frac{15,8}{\sqrt{\frac{(20) 33,99+(19) 25}{21+20-2}\left[\frac{41}{420}\right]}} \\
& t=\frac{15,8}{\sqrt{\frac{679,8+475}{39}[0,098]}} \\
& t=\frac{15,8}{\sqrt{\frac{1154,8}{39}[0,098]}} \\
& t=\frac{15,8}{\sqrt{296,10[0,098]}}=54,5
\end{aligned}
$$


Berdasarkan nilai rata-rata nilai posttest kelas eksperimen $1\left(\bar{X}_{1}=90,2\right)$ dengan standar deviasi $\left(S_{1}=5,83\right)$, dan rata-rata nilai posttest kelas kontrol $\left(\bar{X}_{2}=74,4\right)$ dengan standar deviasi 5 serta jumalah $\mathrm{n}_{1}=21$ dan $\mathrm{n}_{2}=20$, setelah dilakukan perhitungan maka diperoleh $\mathrm{t}_{\text {hitung }} 54,5$

Kemudian menentukan harga $t_{\text {tabel }}$ dimana hasil uji t diatas, dijelaskan bahwa nilai thitung sebesar 54,5 pada dk 41dan taraf signifikansi 0,05 dengan uji dua pihak, untuk menentukkan $t_{\text {tabel }}$ harus menggunakan interpolasi. Hal ini dilakukan karena nilai $t_{\text {tabel }}$ yang sesuai dengan dk 41 tidak tercantum dalam tabel distribusi t. Rumus interpolasi adalah sebagai berikut :

$\mathrm{dk}-\mathrm{dk} \min : \mathrm{dk} \max -\mathrm{dk} \min =\mathrm{X}-\mathrm{t}_{\text {tabel }}$ atas :

( $\mathrm{t}_{\text {tabel }}$ bawah $-\mathrm{t}_{\text {tabel }}$ atas $)$

$\begin{array}{ll}41-40: 60-40 & =\mathrm{X}-2,021:(2,021- \\ & 2,000) \\ 1: 20 & =\mathrm{X}-2,021:(2,021- \\ & 2,000) \\ 20 \mathrm{X}-2,000 & =1(2,021-2,000) \\ 20 \mathrm{X}-40,00 & =(2,021-20.00) \\ 20 \mathrm{X}-40,00 & =0,021 \\ 20 \mathrm{X} & =0,021+40,00 \\ 20 \mathrm{X} & =40,021 \\ \mathrm{X} & =40,021 / 20 \\ \mathrm{X} & =2,00105\end{array}$

Berdasarkan hasil perhitungan interpolasi, maka diperoleh nilai $t_{\text {tabel }}$ sebesar 2,00105. Berikutnya membandingkan $t_{\text {hitung }}$ dengan $t_{\text {tabel }}$ yang diinterpolasi.

Berdasarkan perhitungan rumus uji t-test diperoleh nilai $t_{\text {hitung }} 54,5$ sedangkan nilai $t_{\text {tabel }}$ 2,00105 , maka $t_{\text {hitung }}$ lebih besar dari $t_{\text {tabel. }}$ Hal ini menunjukan bahwa terdapat perbedaan hasil belajar peserta didik menggunakan media pembelajaran AUDITIF pada pengukuran akhir (posttest) di kelas eksperimen dan pengukuran akhir (posttest) di kelas kontrol yang disimpulkan bahwa adanya pengaruh dari penggunaan media auditif yang diterapkan di kelas eksperimen.

Kemudian adapula kaidah pengujian hipotesis yang digunakan pada penelitian ini. Dimana ada dua kemungkinan jawaban yaitu :

1. Jika $t_{\text {hitung }}>t_{\text {tabel, }}$ maka hitungan tersebut signifikan, artinya hipotesis diterima. Dapat disimpulkan bahwa terdapat pengaruh terhadap penggunaan media pembelajaran AUDITIF dikelas eksperimen.

2. Jika $t_{\text {hitung }}<t_{\text {tabel, }}$ maka hitungan tersebut signifikan, atinya hipotesis ditolak. Dapat disimpulkan bahwa tidak terdapat pengaruh terhadap penggunaan media pembelajaran AUDITIF dekelas eksperimen.

\section{KESIMPULAN \\ Simpulan}

Berdasarkan hasil penelitian dan pembahasan yang telah dikemukakan maka peneliti dapat menarik kesimpulan sebagai berikut:

1. Hasil belajar peserta didik kelas eksprimen pada pengukuran awal atau pretest dan pengukuran akhir yang telah dilakukan dengan menggunakan 15 butir soal, pada pengukuran awal dengan rata-rata nilai 38,6 namun belum memenuhi KKM. Dipengukuran akhir atau posttest sesudah diterapkan media pembelajaran auditif dengan rata rata nilai posttest adalah 90,2 dimana bisa disimpulkan peserta didik sudah memenuhi KKM.

2. Terdapat peningkatan hasil belajar terhadap peserta didik kelas eksperimen yang menunakan media pembelajaran auditif dari sebelumnya yang belum menggunakan media pembelajaran auditif atau hanya menggunakam metode ceramah atau belum menggunakan media pembelajaran auditif.

3. Adanya pengaruh posittif dari penggunaan media pembelajaran auditif di kelas eksperimen yang sebelumnya belum menggunakan media pembelajaran terhadap hasil belajar peserta didik, yang dapat dilihat dari pengukuran awal atau pretest dan pengukuran akhir atau posttest, dimana hasil posttets lebih tinggi dari pada hasil pretest.

\section{DAFTAR PUSTAKA}

Djamarah, Syaiful Bahri dan Aswan Zain. 2010. Strategi Belajar Mengajar. Jakarta: Rineka Cipta.

Kustandi. Sujtipto. (2013). Media Pembelajaran. Bogor. Ghalia Indonesia.

Rusman. (2012). Model-model Pembelajaran Mengembangkan Profesionalisme Guru. Jakarta. Raja Grafindo Persada.

Rusman. (2017). Belajar \& Pembelajaran. Jakarta. Kencana.

Sugiyono. (2017). Metode Penelitian Kuantitatif, Kualitatif, dan $R \& D$. Bandung. Alfabeta.

Sugiyono. (2017). Statistika Untuk Penelitian. Bandung. Alfabeta. 